\title{
The Role of Histamine and Histamine Receptors in Mast Cell-Mediated Allergy and Inflammation: The Hunt for New Therapeutic Targets
}

\author{
Elden Berla Thangam ', Ebenezer Angel Jemima', Himadri Singh², Mirza Saqib Baig ${ }^{3}$, \\ Mahejibin Khan ${ }^{4}$, Clinton B. Mathias ${ }^{5}$, Martin K. Church ${ }^{6}$ and Rohit Saluja2,7*
}

\begin{abstract}
'Department of Biotechnology, School of Bioengineering, SRM Institute of Science and Technology, Kattankulathur, Tamil Nadu, India, ${ }^{2}$ Department of Biochemistry, All India Institute of Medical Sciences, Bhopal, Madhya Pradesh, India, ${ }^{3}$ Discipline of Biosciences and Biomedical Engineering (BSBE), Indian Institute of Technology Indore (IITI), Indore, Madhya Pradesh, India, ${ }^{4}$ Central Food Technological Research Institute-Resource Centre, Lucknow, India, ${ }^{5}$ Department of Pharmaceutical and Administrative Sciences, Western New England University, Springfield, MA, United States, ${ }^{6}$ Department of Dermatology and Allergy, Charité - Universitätsmedizin Berlin, Berlin, Germany, ${ }^{7}$ Department of Biotechnology, Government of India, New Delhi, India
\end{abstract}

OPEN ACCESS

Edited by:

Carlo Pucillo,

Università degli Studi di Udine, Italy

Reviewed by:

Axel Lorentz,

University of Hohenheim, Germany

Meenu Sharma,

University of Texas MD Anderson

Cancer Center, United States

*Correspondence:

Rohit Saluja

drrohitsaluja@gmail.com,

rohit.biochemistry@aiimsbhopal.edu.in

Specialty section:

This article was submitted to

Molecular Innate Immunity,

a section of the journal

Frontiers in Immunology

Received: 14 March 2018

Accepted: 30 July 2018

Published: 13 August 2018

Citation:

Thangam EB, Jemima EA, Singh $H$, Baig MS, Khan M, Mathias CB,

Church MK and Saluja R (2018) The Role of Histamine and Histamine

Receptors in Mast Cell-Mediated Allergy and Inflammation: The Hunt for New Therapeutic Targets.

Front. Immunol. 9:1873.

doi: 10.3389/fimmu.2018.01873
Histamine and its receptors ( $\mathrm{H} 1 \mathrm{R}-\mathrm{H} 4 \mathrm{R})$ play a crucial and significant role in the development of various allergic diseases. Mast cells are multifunctional bone marrow-derived tissue-dwelling cells that are the major producer of histamine in the body. H1R are expressed in many cells, including mast cells, and are involved in Type 1 hypersensitivity reactions. H2R are involved in Th1 lymphocyte cytokine production. H3R are mainly involved in blood-brain barrier function. $\mathrm{H} 4 \mathrm{R}$ are highly expressed on mast cells where their stimulation exacerbates histamine and cytokine generation. Both $\mathrm{H} 1 \mathrm{R}$ and $\mathrm{H} 4 \mathrm{R}$ have important roles in the progression and modulation of histamine-mediated allergic diseases. Antihistamines that target H1R alone are not entirely effective in the treatment of acute pruritus, atopic dermatitis, allergic asthma, and other allergic diseases. However, antagonists that target H4R have shown promising effects in preclinical and clinical studies in the treatment of several allergic diseases. In the present review, we examine the accumulating evidence suggesting novel therapeutic approaches that explore both $\mathrm{H} 1 \mathrm{R}$ and $\mathrm{H} 4 \mathrm{R}$ as therapeutic targets for histamine-mediated allergic diseases.

Keywords: histamine, histamine receptors, mast cells, allergy, inflammation, antihistamines

\section{INTRODUCTION}

Allergic diseases, for example, allergic asthma, pruritus, atopic dermatitis, and allergic rhinitis are due to a complex interaction between several inflammatory cells, including basophils, mast cells, lymphocytes, dendritic cells, neutrophils, and eosinophils in response to various environmental/ allergic stimuli $(1,2)$. These cells produce a plethora of inflammatory mediators, such as histamine,

\footnotetext{
Abbreviations: BMMCs, bone marrow-derived murine mast cells; ERK, extracellular signal-regulated kinases; GM-CSF granulocyte macrophage colony stimulating factor; $\mathrm{H} 1 \mathrm{R}$, histamine $\mathrm{H} 1$ receptor; $\mathrm{H} 2 \mathrm{R}$, histamine $\mathrm{H} 2$ receptor; $\mathrm{H} 3 \mathrm{R}$, histamine H3 receptor; H4R, histamine H4 receptor; IFN- $\gamma$, interferon- $\gamma$; IL, interleukin; MCP-1, monocyte chemotactic protein-1; NGF, nerve growth factor; PKC, protein kinase C; TNF, tumor necrosis factor; RANTES, regulated on activation T cell expressed and secreted; PBMC, peripheral blood mononuclear cells; THP-1, Tamm-Horsfall protein 1.
} 
eicosanoids, chemokines, cytokines, and reactive oxygen species $(3,4)$. Among these, mast cell histamine is an axial player in stimulating the development of allergic-related inflammatory diseases by regulating the maturation and activation of leukocytes and directing their migration to target sites where they cause chronic inflammation (5-8). Histamine also exerts a various other immune regulatory functions by modulating the functions of monocytes (9), T cells $(10,11)$, macrophages (12), neutrophils (13), eosinophils (14), B cells, and dendritic cells (15). The biological impact of histamine follow their interaction with four types histamine receptors, $\mathrm{H} 1 \mathrm{R}, \mathrm{H} 2 \mathrm{R}, \mathrm{H} 3 \mathrm{R}$, and $\mathrm{H} 4 \mathrm{R}$, all of which belong to the $\mathrm{G}$ protein coupled receptor family $(8,16-20)$.

In this review, we focus on the importance and present knowledge about the histamine and histamine receptor-mediated activation in mast cell-mediated allergic disorders.

\section{Mast Cells: Source of Histamine}

Mast cells are the major producer of histamine and express a vast array of receptors on their surface such as FceR1, FcyRI, and receptors for complement components ( $\mathrm{C} 3 \mathrm{aR}$ and $\mathrm{C} 5 \mathrm{aR})$, nerve growth factor (NGF) (Trk A), substance P, vasoactive intestinal peptide (MrgX2), adenosine phosphate, etc. (21-24). Activation through these receptors by their respective stimulants, such as allergens, complement peptides C3a, C5a (25, 26), NGF (27), neuropeptides, adenosine mono-phosphate activate human cord blood-derived mast cells to release various inflammatory mediators including histamine. Histamine can also be produced by basophils and other immune cells (28) but much higher concentrations of histamine may be found in intestinal mucosa, skin, and bronchial tissues. Histamine regulates a plethora of pathophysiological and physiological processes, such as secretion of gastric acid, inflammation, and the regulation of vasodilatation and bronchoconstriction $(29,30)$. In addition, it can also serve as a neurotransmitter (31).

\section{Role of Histamine in Allergic Disease}

Histamine plays a central role in the pathogenesis of several allergic diseases, such as atopic dermatitis, allergic rhinitis, and allergic asthma through differential regulation of $\mathrm{T}$ helper lymphocytes. Enhancement of Th2 cytokine secretion [such as interleukin (IL)-5, IL-4, IL-10, and IL-13] and inhibition of Th1 cytokine production [interferon- $\gamma($ IFN- $\gamma)$, monokine IL-12, and IL-2] are mediated by histamine. Thereby, histamine regulates the effective balance between Th1 and Th2 cells by assisting a shift toward Th2 (32). Histamine-mediated mast cell activation plays a critical role in various allergic diseases. Histamine may induce the release of leukotrienes, cytokines, and chemokines via $\mathrm{H} 4 \mathrm{R}$ in $\mathrm{CD} 34^{+}$cord blood-derived human mast cells (33). In mouse mast cells, both histamine and 4-methylhistamine can induce IL-6 production individually, an effect that is potentiated by LPS stimulation. This effect can be blocked by H4R antagonists and does not occur in H4R-deficient allergic mice (34). Recent findings have shown that activation of $\mathrm{H} 4$ receptors by histamine stimulates the synthesis of IL-4 and IL-5 in human cord blood mast cells and tumor necrosis factor (TNF)- $\alpha$ in bone marrow-derived murine mast cells (BMMCs), both of which have a potential role in inducing allergic inflammation $(33,35)$.

\section{HISTAMINE RECEPTORS AND THEIR ROLE IN ALLERGIC INFLAMMATION}

Histamine receptors (H1R-H4R) are characterized by their function, structure, distribution, and their affinity to histamine $(36,37)$. Histamine has diverse effects, both pro-inflammatory and anti-inflammatory, which are determined by both the histamine receptor subtype and the cells stimulated types (38). The H1-receptor drives cellular migration, nociception, vasodilatation, and bronchoconstriction (39), whereas the H2-receptor modifies gastric acid secretion, airway mucus production, and vascular permeability (40). The H3-receptor plays an important role in neuro-inflammatory diseases (37). The H4-receptor has also been shown to be involved in allergy and inflammation (38, 41). H4R-mediated mast cell activation can regulate a powerful inflammatory cascade by releasing several inflammatory mediators; these mediators may stimulate the migration of different inflammatory cells into the inflammatory site (33). Likewise, the activation of $\mathrm{H} 1 \mathrm{R}$ also regulates allergic responses by enhancing the migration of Th2 cells toward the allergen during lung inflammation (42). A more detailed summary of histamine receptor expression is shown in Table 1.

\section{The H1-Receptor}

The H1R is ubiquitously expressed and is involved in allergy and inflammation. H1R is expressed in many tissues and cells, including nerves, respiratory epithelium, endothelial cells, hepatic cells, vascular smooth muscle cells, dendritic cells, and lymphocytes $(8,19)$. Histamine activates H1R through Goq/11, which then activates phospholipase $\mathrm{C}$ and increases intracellular $\mathrm{Ca}^{++}$levels. As a consequence, histamine elicits the contraction of smooth muscle of the respiratory tract, increases vascular permeability, and induces the production of prostacyclin and platelet activating factor by activating H1R (Figure 1) (58). Thus, almost all immediate hypersensitivity reactions, including symptoms observed in the skin, such as erythema, pruritus, and edema, may be elicited by the activation of H1R (59).

Activation via H1R may also enhance both Th1- and Th2-type immune responses (11). In mice, deletion of H1R leads to the release of Th2 cytokines (IL-4 and IL-13) and inhibition of IFN- $\gamma$ (60). Similarly, Bryce et al. (42) demonstrated that allergenchallenged H1R-deficient mice had attenuated lung allergic responses. They also demonstrated that histamine may act as a chemotactic factor for Th2 cells, stimulating their migration into lung tissues (42).

In addition, IL-3 activation can increase H1R expression on Th1 cells $(61,62)$, and histamine can enhance B cell proliferation, which is absent in H1R-deficient mice (63). The role of H1R activation in asthma may be further corroborated by observations showing that use of H1R-antagonists can significantly decrease asthma symptoms and improve pulmonary function in persistent asthma $(58,64,65)$.

Histamine $\mathrm{H} 1$ receptor is also expressed in dermal dendritic cells and keratinocytes in the skin tissue, and histamine increases the NGF production via H1R in human keratinocytes (66). The secretion of NGF is caused by the phosphorylation of protein kinase C, extracellular signal-regulated kinases (ERK), and the 
TABLE 1 | Expression of different histamine receptors on various cells.

\begin{tabular}{|c|c|c|c|}
\hline $\begin{array}{l}\text { Histamine } \\
\text { receptors }\end{array}$ & G-proteins & Expression on various cells & Reference \\
\hline $\mathrm{H} 1 \mathrm{R}$ & $\mathrm{Gq} / 11$ & $\begin{array}{l}\text { Human mast cells (skin, LAD2, } \\
\text { intestinal mast cells) } \\
\text { Tamm-Horsfall protein } 1 \text { (THP-1) } \\
\text { Nerve cells } \\
\text { T-cells } \\
\text { Airway and vascular smooth muscles } \\
\text { Endothelial cells } \\
\text { Epithelial cells } \\
\text { Hepatocytes } \\
\text { Chondrocytes } \\
\text { Basophils } \\
\text { B cells } \\
\text { Peripheral blood mononuclear cell } \\
\text { (PBMC) } \\
\text { Eosinophils } \\
\text { Neutrophils } \\
\text { Dendritic cells } \\
\text { Natural killer cells } \\
\text { SW756 cervical carcinoma cells } \\
\text { Conjunctival fibroblast } \\
\text { Macrophage }\end{array}$ & $\begin{array}{l}(43-45) \\
(33,46) \\
(19) \\
(10,11,19) \\
(19) \\
(19) \\
(47) \\
(19) \\
(19) \\
(19) \\
(19) \\
(45) \\
(19) \\
(19) \\
(15,19) \\
(15) \\
(44) \\
(48) \\
(12)\end{array}$ \\
\hline & $\mathrm{G} \alpha \mathrm{S}$ & $\begin{array}{l}\text { Human mast cells (skin, LAD2) } \\
\text { THP-1 } \\
\text { T-cells } \\
\text { Conjunctival fibroblast } \\
\text { Eosinophils } \\
\text { PBMCs } \\
\text { Airway and vascular smooth } \\
\text { muscles } \\
\text { Endothelial cells } \\
\text { Epithelial cells } \\
\text { Hepatocytes } \\
\text { Chondrocytes } \\
\text { Nerve cells } \\
\text { B cells } \\
\text { Monocytes } \\
\text { Basophils } \\
\text { Neutrophils } \\
\text { SW756 cervical carcinoma cells }\end{array}$ & $\begin{array}{l}(43,44) \\
(46) \\
(10,11,49) \\
(48) \\
(50) \\
(51,52) \\
(19) \\
(19,40) \\
(19) \\
(19) \\
(19) \\
(19) \\
(19) \\
(19) \\
(19) \\
(53) \\
(44)\end{array}$ \\
\hline H3R & Gi/o & $\begin{array}{l}\text { Neuroblastoma cell line } \\
\text { MHH-NB-11 } \\
\text { Dendritic cells } \\
\text { Eosinophils } \\
\text { Histaminergic neurons } \\
\text { Mast cells (LAD2) }\end{array}$ & $\begin{array}{l}(45) \\
(19) \\
(19) \\
(19) \\
(44)\end{array}$ \\
\hline $\mathrm{H} 4 \mathrm{R}$ & Gi/os & $\begin{array}{l}\text { Human mast cells (skin, LAD2, } \\
\text { HMC-1, cord blood mast cells, } \\
\text { intestinal mast cells) } \\
\text { Bone marrow and peripheral } \\
\text { hematopoietic cells } \\
\text { THP-1 } \\
\text { SW756 cervical carcinoma cells } \\
\text { Nerve cells } \\
\text { Conjunctival fibroblast } \\
\text { PBMC } \\
\text { T-cells } \\
\text { Natural killer cells } \\
\text { Basophils } \\
\text { Eosinophils } \\
\text { Neutrophils } \\
\text { Monocytes-derived dendritic cells } \\
\text { Macrophage } \\
\text { Myeloid cells } \\
\text { Dendritic cells }\end{array}$ & $\begin{array}{l}(19) \\
(33) \\
(44) \\
(40) \\
(48) \\
(45) \\
(19,49,54) \\
(15) \\
(6,55) \\
(5,7,50) \\
(19,40) \\
(56) \\
(40) \\
(57) \\
(15,19)\end{array}$ \\
\hline
\end{tabular}

activation of AP-1 resulting from H1R stimulation. Similarly, histamine, acting via $\mathrm{H} 1 \mathrm{R}$, has also been shown to enhance the production of chemokines, such as granulocyte macrophage colony stimulating factor, regulated on activation $\mathrm{T}$ cell expressed and secreted (RANTES), and monocyte chemotactic protein-1 (MCP-1) in IFN- $\gamma$-stimulated keratinocytes. It also upregulates the antigen-presenting capability of dendritic cells, and leads to Th1 polarization through H1R (67).

Histamine induces IL-31 production, which plays an important and crucial role in pruritus and skin barrier function in allergic dermatitis (54). Administration of an H1R antagonist decreased IL-31 levels in the serum of atopic dermatitis patients (68). These data therefore suggest that H1R activation by histamine has the ability to induce various symptoms related with allergic skin diseases such as pruritus and atopic dermatitis.

\section{The H2-Receptor}

The Gos-coupled H2R is highly expressed in various cells and tissues, such as B cells, $\mathrm{T}$ cells, dendritic cells, gastricparietal cells, smooth muscle cells, and the brain and cardiac tissues (Table 1). Activation of the receptor can induce airway mucus production, vascular permeability, and secretion of gastric acid (69). The role of the H2R is well studied in histidine decarboxylase knockout mice (HDC ${ }^{--}$) models which suggest that the lack of histamine can enhance downregulation of $\mathrm{H} 2 \mathrm{R}$ expression in a tissue-specific manner (70). Furthermore, the $\mathrm{H} 2 \mathrm{R}$ is importantly accountable for the relaxation of the airways, uterus, and smooth muscle cells in the blood vessels. Moreover, the $\mathrm{H} 2 \mathrm{R}$ is involved in the activation of the immune system, such as Th 1 cytokine production, reduction of basophil degranulation, T-cell proliferation, and antibody synthesis $(71,72)$. Knockdown of $\mathrm{H}_{2} \mathrm{R}^{-/-}$mice show impaired immune functions, gastric acid secretion, and cognitive function associated with hippocampal potentiation impairments $(73,74)$ and nociception abnormalities (75).

\section{The H3-Receptor}

The H3R is coupled to Gai/o and exclusively expressed in neurones. It is important for homeostatic regulation of energy levels, sleep-wake cycle, cognition, and inflammation (76) (Figure 1). H3R-deficient mice exhibit altered behavior and locomotion (77) and display a metabolic syndrome characterized by obesity, hyperphagia, and increased leptin and insulin levels $(78,79)$. Similarly, several studies suggest that H3R knockout can also lead to an increase in severity of neuro-inflammatory diseases and can enhance the expression of IFN-inducible protein 10, MIP 2, and CXCR3 in T cells (80). These investigators also showed that H3R can be involved in blood-brain barrier function.

The H3R has also been associated with rhinitis (81). This is likely because it is expressed on presynaptic nerves in the peripheral sympathetic adrenergic system and also on nasal sub-mucosal glands. Stimulation of H3R suppressed norepinephrine release at presynaptic nerve endings and stimulated nasal sub-mucosal gland secretion (82).

Currently, several H3R ligands are available, but not in clinical use. H3R antagonists, such as clobenpropit and thioperamide, were extensively used as a research tools and 


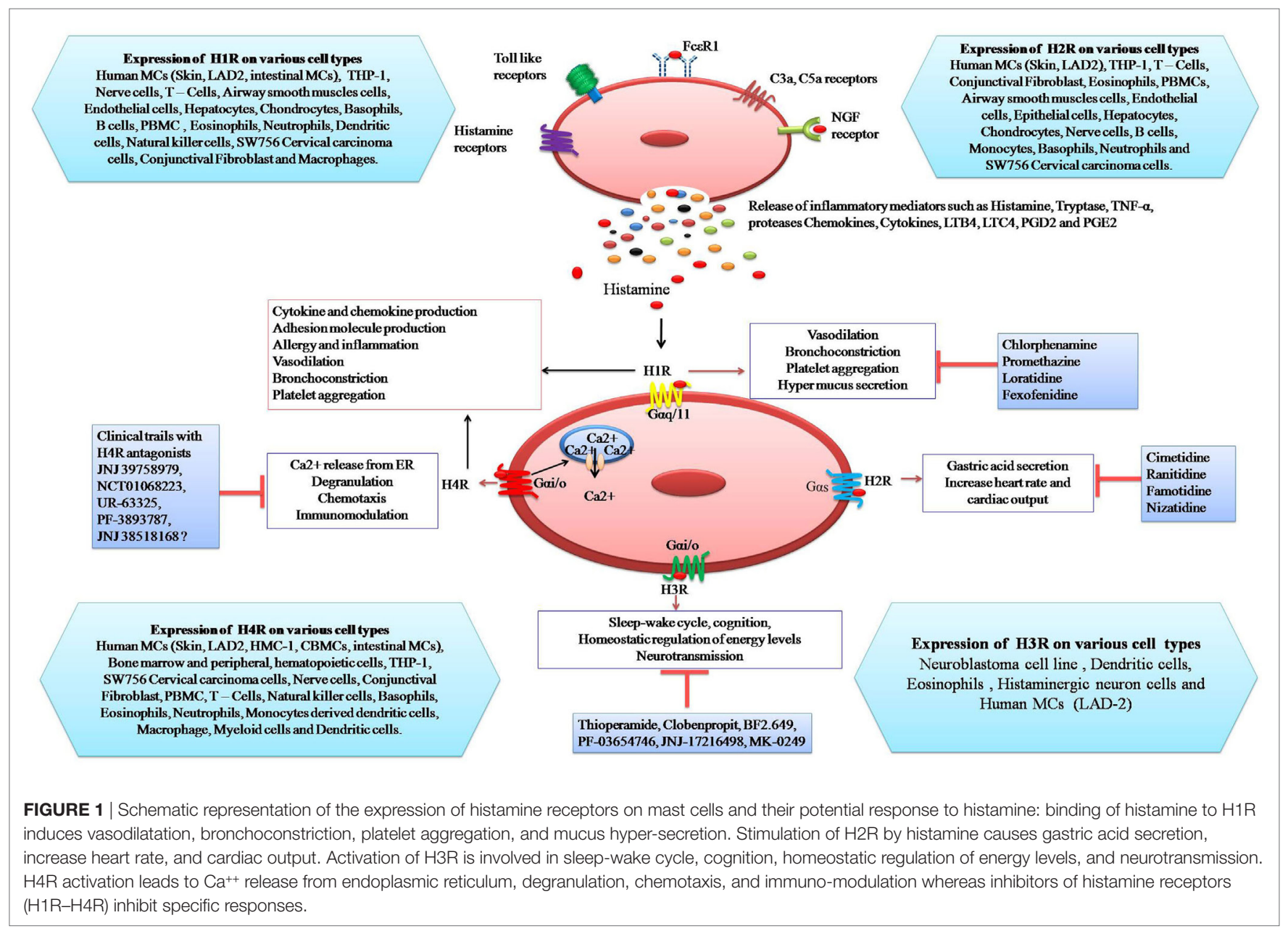

few early stage clinical trial reports are also available for $\mathrm{H} 3 \mathrm{R}$ antagonists (83). However, these antagonists are used to treat obesity, myocardial ischemic arrhythmias, cognition disorders, and insomnia (84).

\section{The H4-Receptor}

The histamine H4R is coupled to Go/io proteins (85) and is expressed on a variety of immune cells as well as on other cells such as spleen, intestinal epithelia, lung, synovial tissue, central nervous system, sensory neurons, and cancer cells (86-94). Stimulation of H4R reduces forskolin-induced cyclic AMP formation, which leads to the activation of MAPK and enhanced $\mathrm{Ca}^{++}$ release $(6,95)$. H4R mediates the pro-inflammatory responses of histamine in both autocrine and paracrine manners. Histamine enhances adhesion molecule expression, cell shape change, and cytoskeletal rearrangement via $\mathrm{H} 4 \mathrm{R}$, leading to the increased migration of eosinophils (5).

In various allergic diseases allergen cross linkage of FceRI is the primary driver of mast cell activation. However, H4R is constitutively expressed on human mast cells such as LAD-2 and HMC-1 $(33,43)$. H4R-mediated activation of mast cells leads to the expression of various pro-inflammatory cytokine and chemokines, such as IL- 6 , TNF- $\alpha$, TGF- $\beta 1$, RANTES, IL-8,
MIP- $1 \alpha$, and MCP-1 (33). Histamine H4R stimulation of mast cells may have three positive effects. First, it increases chemotaxis of mast cells thus encouraging their accumulation at the site of an allergic response (6). Second, it upregulates the expression of FceRI on mast cells, thereby priming them for allergen-induced activation (96). Third, it mobilizes intracellular calcium to either prime mast cells for activation or, indeed, induce degranulation. These effects have been studied using histamine, the H4R-agonist 4-methylhistamine, the H4R-antagonists thioperamide or JNJ 7777120 and mast cells from H4R-deficient mice.

Basophils also express H4R on their surface and release histamine following antigen stimulation (55). However, basophils and mast cells differ in several important aspects, such as anatomical localization, the production of cytokines, and antigen-presenting activity. Histamine, acting via H4R, induces chemotaxis of bone marrow-derived basophils. H4R may play significant roles in basophil regulation in allergic dermatitis (97).

Among the Th subsets, the mRNA and protein of H4R are preferentially expressed in Th2 cells over naive $\mathrm{T}$ cells and Th1 cells. H4R may be involved in the pathogenesis of allergy and inflammation by activating Th2 as well as Th17 cells $(68,98)$. In human Th17 cells, H4R antagonists inhibit the IL-17 production, induced by H4R agonist (68). 
Stimulation of H4R can also enhance the migration of eosinophils and the recruitment of mast cells leading to the amplification of immune responses and chronic inflammation. Similarly, H4R are involved in T cell differentiation and dendritic cell activation and its immunomodulatory function (6). Histamine and selective H4R agonists were shown to induce the shape change of eosinophils, an effect that maybe blocked by selective H4R antagonists (5). Treatment with JNJ 39758979 (H4R antagonist) resulted in a statistically significant inhibition of eosinophil shape change. These results showed that administration of H4R antagonists may have an impact on eosinophil function (38).

Finally, the activation of $\mathrm{H} 4 \mathrm{R}$ involves several signaling cascades for the release of various allergic inflammatory mediators. ERK is a member of MAPK family and mediates the proliferation, differentiation, anti-apoptosis, regulation, and cytokine expression at gene level. There are reports showing that histamine can induce phosphorylation of ERK through $\mathrm{H} 4 \mathrm{R}$ in peripheral blood derived $\mathrm{CD} 34^{+}$human mast cells as well as in mouse BMMCs (34) and HEK-293 cells (99). H4Rinvolved ERK and PI3 kinase pathways have been shown to be involved in the release of IL-6 in mouse BMMCs (34) and JAK/ STAT signaling pathways for the release of TNF- $\alpha$ in a rat model (100). Recent studies (101) demonstrated that the activation of NFKB through H4R has followed the JAK/STAT signaling pathway.

\section{H4R: A NOVEL DRUG TARGET FOR ALLERGIC DISEASES}

In addition to H1R, H4R is considered as a novel drug target for the treatment of allergy and inflammation. Recently, the H4R antagonists such as JNJ 7777120 and JNJ 39758979 have been extensively used as a tools to understand the pathophysiological involvement of H4R and have been studied extensively in both cell culture and in vivo animal models $(102,103)$. Furthermore, $\mathrm{H} 4 \mathrm{R}$ antagonists have been used to explore the role of H4R in allergic inflammatory disorders, such as allergic asthma, allergic rhinitis, and chronic pruritus (31).

\section{ROLE OF ANTIHISTAMINES IN MAST CELL-ASSOCIATED DISEASES}

Mast cells play an active role in various allergic diseases such as acute pruritus, atopic dermatitis, allergic asthma, allergic rhinitis, and pulmonary fibrosis $(104,105) . \mathrm{H}_{1}$-antihistamines, such as azatadine, cetirizine, and mizolastine are used for the treatment mast cell activated diseases (106). Cimetidine, ranitidine, famotidine, and nizatidine are $\mathrm{H} 2 \mathrm{R}$ selective antihistamines that reduce gastric acid secretion (107). H3R antihistamines include thioperamide, clobenpropit, BF2. 649, PF-03654746, JNJ-17216498, and MK 0249.

JNJ 7777120 is a selective H4R antihistamine that is widely used in inflammation and pruritus (108). There are some H4R antihistamines which are under clinical trial, such as JNJ 39758979, NCT 01068223, UK-63325, PF-3893787, and JNJ 38518168
(Figure 1) $(108,109) . \mathrm{H}_{1}$-antihistamines are a standard treatment for mast cell-mediated allergic diseases. There is increasing evidence that histamine binding to $\mathrm{H} 4$ receptors exacerbates allergy and inflammation. Indeed, mast cells themselves have H4 receptors which when stimulated increased degranulation and cytokine production. Therefore, antihistamines targeting both the $\mathrm{H} 1$ and $\mathrm{H} 4$ receptor could be an effective treatment for mast cell-mediated allergic diseases (110).

\section{CLINICAL TRIALS TARGETING HISTAMINE RECEPTORS}

Pharmacological properties of H4R have been exhibited by various H4R transfected cells $(87,89,99,111,112)$. It was observed that H1R and H2R specific agonist/antagonists cannot bind to the H4R. However, some H3R ligands such as imetit, clobenpropit, thioperamide, and $R$-methylhistamine are also able to bind to the H4R with different affinities. Currently, a number of H4R antagonists have been developed but only a few are undergoing clinical trials. JNJ 39758979, a potent and selective H4R antagonist, has shown impressive results in different allergic inflammatory diseases such as dermatitis, asthma, pruritus, and arthritis (102, 103).

Recent clinical trials (NCT01068223) with the H4R antagonist JNJ 39758979 help to demonstrate a significant role of the H4 receptor in pruritus in humans. Interestingly, the combination therapy of this H4R antagonist and the H1R antihistamine, cetirizine, showed a more beneficial effect in the treatment of pruritus as compared with H1R alone (113-116). Furthermore, a study was carried out by using JNJ 39758979 to treat persistent asthma (NCT00946569), but no results have yet been reported. There are some H4R antagonists under the clinical trial including toreforant (JNJ 38518168), PF-3893787, and UR-63325. Toreforant (JNJ 38518168) has been used for the treatment of rheumatoid arthritis (clinical trial numbers: NCT01679951, NCT00941707, and NCT01862224). However, a study in rheumatoid arthritis (NCT01679951) was terminated due to issues related to efficacy. Even though, studies are still going on with the H4R antagonist toreforant (JNJ 38518168) in patients with asthma and psoriasis (clinical trial numbers NCT01823016 and NCT02295865, respectively) (38).

\section{CONCLUSION AND FUTURE PROSPECTIVE}

The recent developments in research on histamine pathway underscore the importance of histamine in allergic inflammation through its effects on the H1R and H4R. Although, drugs targeting H1R are being explored for the treatment of various mast cell-associated allergic disorders, they are not always clinically effective. Several H4R antagonists have entered the later stages of clinical trials for a different range of allergic and inflammatory diseases. However, their clinical efficacy reports are not yet published. Furthermore, there appears to be some overlap in function between H1R and H4R, opening up the possibility for using synergistic strategies for therapeutic approaches. As such, 
we suggest the combination therapies by using both H4R together with H1R antagonists may provide a potential benefit in the treatment of various allergic and inflammatory diseases.

\section{AUTHOR CONTRIBUTIONS}

ET, EJ, HS, MB, MK, CM, MC, and RS designed the manuscript; were involved in drafting/revising the manuscript; and read and approved the final manuscript. ET, EJ, and RS wrote the first draft.

\section{FUNDING}

This work was primarily supported by DBT, Government of India, Ref. No: BT/PR3230/BRB/10/965/2011. ET and EJ thank SRM Institute of Science and Technology for the constant support and institutional facilities throughout the study. RS (BT/ RLF/Re-entry/53/2013) and MB (BT/RLF/Re-entry/26/2013) acknowledge support from the Department of Biotechnology, India for Ramalingaswami Re-entry Fellowship.

\section{REFERENCES}

1. Rothenberg ME. Eosinophilia. N Engl J Med (1998) 338:1592-600. doi:10.1056/NEJM199805283382206

2. Kay AB. Allergy and allergic diseases. First of two parts. N Engl J Med (2001) 344:30-7. doi:10.1056/NEJM200101043440106

3. Gordon JR, Galli SJ. Mast cells as a source of both preformed and immunologically inducible TNF-alpha/cachectin. Nature (1990) 346:274-6. doi: $10.1038 / 346274 \mathrm{a} 0$

4. Young JD, Liu CC, Butler G, Cohn ZA, Galli SJ. Identification, purification, and characterization of a mast cell-associated cytolytic factor related to tumor necrosis factor. Proc Natl Acad Sci U S A (1987) 84:9175-9. doi:10.1073/ pnas.84.24.9175

5. Buckland KF, Williams TJ, Conroy DM. Histamine induces cytoskeletal changes in human eosinophils via the $\mathrm{H}(4)$ receptor. Br J Pharmacol (2003) 140:1117-27. doi:10.1038/sj.bjp.0705530

6. Hofstra CL, Desai PJ, Thurmond RL, Fung-Leung WP. Histamine H4 receptor mediates chemotaxis and calcium mobilization of mast cells. J Pharmacol Exp Ther (2003) 305:1212-21. doi:10.1124/jpet.102.046581

7. O’Reilly M, Alpert R, Jenkinson S, Gladue RP, Foo S, Trim S, et al. Identification of a histamine $\mathrm{H} 4$ receptor on human eosinophils - role in eosinophil chemotaxis. JRecept Signal Transduct Res (2002) 22:431-48. doi:10.1081/RRS-120014612

8. Thurmond RL, Desai PJ, Dunford PJ, Fung-Leung WP, Hofstra CL, Jiang $\mathrm{W}$, et al. A potent and selective histamine $\mathrm{H} 4$ receptor antagonist with anti-inflammatory properties. J Pharmacol Exp Ther (2004) 309:404-13. doi:10.1124/jpet.103.061754

9. Laszlo V, Rothe G, Hegyesi H, Szeberenyi JB, Orso E, Schmitz G, et al. Increased histidine decarboxylase expression during in vitro monocyte maturation; a possible role of endogenously synthesised histamine in monocyte/ macrophage differentiation. Inflamm Res (2001) 50:428-34. doi:10.1007/ PL00000266

10. Jutel M, Watanabe T, Klunker S, Akdis M, Thomet OA, Malolepszy J, et al. Histamine regulates T-cell and antibody responses by differential expression of H1 and H2 receptors. Nature (2001) 413:420-5. doi:10.1038/ 35096564

11. Jutel M, Klunker S, Akdis M, Malolepszy J, Thomet OA, Zak-Nejmark T, et al. Histamine upregulates Th1 and downregulates Th2 responses due to different patterns of surface histamine 1 and 2 receptor expression. Int Arch Allergy Immunol (2001) 124:190-2. doi:10.1159/000053707

12. Triggiani M, Gentile M, Secondo A, Granata F, Oriente A, Taglialatela M, et al. Histamine induces exocytosis and IL-6 production from human lung macrophages through interaction with $\mathrm{H} 1$ receptors. J Immunol (2001) 166:4083-91. doi:10.4049/jimmunol.166.6.4083

13. Hirasawa N, Ohtsu H, Watanabe T, Ohuchi K. Enhancement of neutrophil infiltration in histidine decarboxylase-deficient mice. Immunology (2002) 107:217-21. doi:10.1046/j.1365-2567.2002.01482.x

14. Ling P, Ngo K, Nguyen S, Thurmond RL, Edwards JP, Karlsson L, et al. Histamine $\mathrm{H} 4$ receptor mediates eosinophil chemotaxis with cell shape change and adhesion molecule upregulation. Br JPharmacol (2004) 142:161-71. doi:10.1038/sj.bjp.0705899

15. Damaj BB, Becerra CB, Esber HJ, Wen Y, Maghazachi AA. Functional expression of H4 histamine receptor in human natural killer cells, monocytes, and dendritic cells. J Immunol (2007) 179:7907-15. doi:10.4049/jimmunol. 179.11.7907

16. Parsons ME, Ganellin CR. Histamine and its receptors. Br J Pharmacol (2006) 147(Suppl 1):S127-35. doi:10.1038/sj.bjp.0706440

17. O'Sullivan MP, Tyner JW, Holtzman MJ. Apoptosis in the airways: another balancing act in the epithelial program. Am J Respir Cell Mol Biol (2003) 29:3-7. doi:10.1165/rcmb.F273

18. Jutel $\mathrm{M}$, Blaser $\mathrm{K}$, Akdis CA. Histamine in allergic inflammation and immune modulation. Int Arch Allergy Immunol (2005) 137:82-92. doi: $10.1159 / 000085108$

19. Akdis CA, Simons FE. Histamine receptors are hot in immunopharmacology. Eur J Pharmacol (2006) 533:69-76. doi:10.1016/j.ejphar.2005.12.044

20. Packard KA, Khan MM. Effects of histamine on Th1/Th2 cytokine balance. Int Immunopharmacol (2003) 3:909-20. doi:10.1016/S1567-5769(02)00235-7

21. Metz M, Siebenhaar F, Maurer M. Mast cell functions in the innate skin immune system. Immunobiology (2008) 213:251-60. doi:10.1016/j. imbio.2007.10.017

22. Saito H. Mast cell research. Chem Immunol Allergy (2014) 100:165-71. doi: $10.1159 / 000358733$

23. Metcalfe DD, Baram D, Mekori YA. Mast cells. Physiol Rev (1997) 77:1033-79. doi:10.1152/physrev.1997.77.4.1033

24. Tatemoto K, Nozaki Y, Tsuda R, Konno S, Tomura K, Furuno M, et al. Immunoglobulin E-independent activation of mast cell is mediated by $\mathrm{Mrg}$ receptors. Biochem Biophys Res Commun (2006) 349:1322-8. doi:10.1016/j. bbrc.2006.08.177

25. Theoharides TC. The mast cell: a neuroimmunoendocrine master player. Int J Tissue React (1996) 18:1-21.

26. Theoharides TC, Cochrane DE. Critical role of mast cells in inflammatory diseases and the effect of acute stress. JNeuroimmunol (2004) 146:1-12. doi:10.1016/j.jneuroim.2003.10.041

27. Tal M, Liberman R. Local injection of nerve growth factor (NGF) triggers degranulation of mast cells in rat paw. Neurosci Lett (1997) 221:129-32. doi:10.1016/S0304-3940(96)13318-8

28. Saluja R, Ketelaar ME, Hawro T, Church MK, Maurer M, Nawijn MC. The role of the IL-33/IL-1RL1 axis in mast cell and basophil activation in allergic disorders. Mol Immunol (2015) 63:80-5. doi:10.1016/j.molimm.2014.06.018

29. Barnes PJ. Histamine receptors in the lung. Agents Actions Suppl (1991) 33:103-22

30. Hill SJ. Multiple histamine receptors: properties and functional characteristics. Biochem Soc Trans (1992) 20:122-5. doi:10.1042/bst0200122

31. Zampeli E, Tiligada E. The role of histamine $\mathrm{H} 4$ receptor in immune and inflammatory disorders. Br JPharmacol (2009) 157:24-33. doi:10.1111/j.1476-5381.2009.00151.x

32. Jutel M, Akdis CA. Histamine as an immune modulator in chronic inflammatory responses. Clin Exp Allergy (2007) 37:308-10. doi:10.1111/j.13652222.2007.02666.x

33. Jemima EA, Prema A, Thangam EB. Functional characterization of histamine H4 receptor on human mast cells. Mol Immunol (2014) 62:19-28. doi:10.1016/j.molimm.2014.05.007

34. Desai P, Thurmond RL. Histamine H(4) receptor activation enhances LPSinduced IL-6 production in mast cells via ERK and PI3K activation. Eur J Immunol (2011) 41:1764-73. doi:10.1002/eji.201040932

35. Zhang B, Alysandratos KD, Angelidou A, Asadi S, Sismanopoulos N, Delivanis DA, et al. Human mast cell degranulation and preformed TNF secretion require mitochondrial translocation to exocytosis sites: relevance to atopic dermatitis. J Allergy Clin Immunol (2011) 127:1522-31.e8 doi:10.1016/j.jaci.2011.02.005 
36. Leurs R, Chazot PL, Shenton FC, Lim HD, De Esch IJ. Molecular and biochemical pharmacology of the histamine H4 receptor. Br J Pharmacol (2009) 157:14-23. doi:10.1111/j.1476-5381.2009.00250.x

37. Singh M, Jadhav HR. Histamine $\mathrm{H} 3$ receptor function and ligands: recent developments. Mini Rev Med Chem (2013) 13:47-57. doi:10.2174/ 138955713804484695

38. Thurmond RL. The histamine H4 receptor: from orphan to the clinic. Front Pharmacol (2015) 6:65. doi:10.3389/fphar.2015.00065

39. Bakker RA, Schoonus SB, Smit MJ, Timmerman H, Leurs R. Histamine H(1)receptor activation of nuclear factor-kappa B: roles for $\mathrm{G}$ beta gamma- and $\mathrm{G}$ alpha(q/11)-subunits in constitutive and agonist-mediated signaling. Mol Pharmacol (2001) 60:1133-42. doi:10.1124/mol.60.5.1133

40. Seifert R, Strasser A, Schneider EH, Neumann D, Dove S, Buschauer A. Molecular and cellular analysis of human histamine receptor subtypes. Trends Pharmacol Sci (2013) 34:33-58. doi:10.1016/j.tips.2012.11.001

41. Tiligada E. Editorial: is histamine the missing link in chronic inflammation? J Leukoc Biol (2012) 92:4-6. doi:10.1189/jlb.0212093

42. Bryce PJ, Mathias CB, Harrison KL, Watanabe T, Geha RS, Oettgen HC. The $\mathrm{H} 1$ histamine receptor regulates allergic lung responses. J Clin Invest (2006) 116:1624-32. doi:10.1172/JCI26150

43. Lippert U, Artuc M, Grutzkau A, Babina M, Guhl S, Haase I, et al. Human skin mast cells express $\mathrm{H} 2$ and $\mathrm{H} 4$, but not $\mathrm{H} 3$ receptors. J Invest Dermatol (2004) 123:116-23. doi:10.1111/j.0022-202X.2004.22721.x

44. Rudolph MI, Boza Y, Yefi R, Luza S, Andrews E, Penissi A, et al. The influence of mast cell mediators on migration of SW756 cervical carcinoma cells. J Pharmacol Sci (2008) 106:208-18. doi:10.1254/jphs.FP0070736

45. Sander LE, Lorentz A, Sellge G, Coeffier M, Neipp M, Veres T, et al. Selective expression of histamine receptors H1R, H2R, and H4R, but not H3R, in the human intestinal tract. Gut (2006) 55:498-504. doi:10.1136/ gut.2004.061762

46. Nagai Y, Tanaka Y, Kuroishi T, Sato R, Endo Y, Sugawara S. Histamine reduces susceptibility to natural killer cells via down-regulation of NKG2D ligands on human monocytic leukaemia THP-1 cells. Immunology (2012) 136:103-14. doi:10.1111/j.1365-2567.2012.03565.x

47. Kawabata M, Ohori J, Kurono Y. Effects of benzalkonium chloride on histamine H1 receptor mRNA expression in nasal epithelial cells. Auris Nasus Larynx (2016) 43:685-8. doi:10.1016/j.anl.2016.02.003

48. Leonardi A, Di Stefano A, Motterle L, Zavan B, Abatangelo G, Brun P. Transforming growth factor-beta/Smad - signalling pathway and conjunctival remodelling in vernal keratoconjunctivitis. Clin Exp Allergy (2011) 41:52-60. doi:10.1111/j.1365-2222.2010.03626.x

49. Gantner F, Sakai K, Tusche MW, Cruikshank WW, Center DM, Bacon KB. Histamine $\mathrm{h}(4)$ and $\mathrm{h}(2)$ receptors control histamine-induced interleukin-16 release from human CD8(+) T cells. J Pharmacol Exp Ther (2002) 303:300-7. doi:10.1124/jpet.102.036939

50. Reher TM, Brunskole I, Neumann D, Seifert R. Evidence for ligand-specific conformations of the histamine $\mathrm{H}(2)$-receptor in human eosinophils and neutrophils. Biochem Pharmacol (2012) 84:1174-85. doi:10.1016/j. bcp.2012.08.014

51. Vannier E, Dinarello CA. Histamine enhances interleukin (IL)-1-induced IL-1 gene expression and protein synthesis via $\mathrm{H} 2$ receptors in peripheral blood mononuclear cells. Comparison with IL-1 receptor antagonist. J Clin Invest (1993) 92:281-7. doi:10.1172/JCI116562

52. Vannier E, Dinarello CA. Histamine enhances interleukin (IL)-1-induced IL-6 gene expression and protein synthesis via $\mathrm{H} 2$ receptors in peripheral blood mononuclear cells. J Biol Chem (1994) 269:9952-6.

53. Burde R, Seifert R. Stimulation of histamine H2- (and H1)-receptors activates $\mathrm{Ca} 2+$ influx in all-trans-retinoic acid-differentiated HL-60 cells independently of phospholipase C or adenylyl cyclase. Naunyn Schmiedebergs Arch Pharmacol (1996) 353:123-9. doi:10.1007/BF00168748

54. Gutzmer R, Mommert S, Gschwandtner M, Zwingmann K, Stark H, Werfel T. The histamine $\mathrm{H} 4$ receptor is functionally expressed on $\mathrm{T}(\mathrm{H}) 2$ cells. J Allergy Clin Immunol (2009) 123:619-25. doi:10.1016/j.jaci.2008.12.1110

55. Mommert S, Kleiner S, Gehring M, Eiz-Vesper B, Stark H, Gutzmer R, et al. Human basophil chemotaxis and activation are regulated via the histamine H4 receptor. Allergy (2016) 71:1264-73. doi:10.1111/all.12875

56. Gutzmer R, Diestel C, Mommert S, Kother B, Stark H, Wittmann M, et al. Histamine $\mathrm{H} 4$ receptor stimulation suppresses Il-12p70 production and mediates chemotaxis in human monocyte-derived dendritic cells. J Immunol (2005) 174:5224-32. doi:10.4049/jimmunol.174.9.5224

57. Capelo R, Lehmann C, Ahmad K, Snodgrass R, Diehl O, Ringleb J, et al. Cellular analysis of the histamine $\mathrm{H} 4$ receptor in human myeloid cells. Biochem Pharmacol (2016) 103:74-84. doi:10.1016/j.bcp.2016.01.007

58. Simons FE. Advances in H1-antihistamines. N Engl J Med (2004) 351:220317. doi:10.1056/NEJMra033121

59. Schaefer U, Schmitz V, Schneider A, Neugebauer E. Histamine induced homologous and heterologous regulation of histamine receptor subtype mRNA expression in cultured endothelial cells. Shock (1999) 12:309-15. doi:10.1097/00024382-199910000-00010

60. Ma RZ, Gao J, Meeker ND, Fillmore PD, Tung KS, Watanabe T, et al. Identification of Bphs, an autoimmune disease locus, as histamine receptor H1. Science (2002) 297:620-3. doi:10.1126/science.1072810

61. Horio S, Fujimoto K, Mizuguchi H, Fukui H. Interleukin-4 up-regulates histamine $\mathrm{H} 1$ receptors by activation of $\mathrm{H} 1$ receptor gene transcription. Naunyn Schmiedebergs Arch Pharmacol (2010) 381:305-13. doi:10.1007/ s00210-010-0491-z

62. Osna N, Elliott K, Khan MM. Regulation of interleukin-10 secretion by histamine in TH2 cells and splenocytes. Int Immunopharmacol (2001) 1:85-96. doi:10.1016/S0162-3109(00)00268-X

63. Banu Y, Watanabe T. Augmentation of antigen receptor-mediated responses by histamine H1 receptor signaling. JExp Med (1999) 189:673-82. doi:10.1084/jem.189.4.673

64. Baena-Cagnani CE, Berger WE, Dubuske LM, Gurne SE, Stryszak P, Lorber R, et al. Comparative effects of desloratadine versus montelukast on asthma symptoms and use of beta 2-agonists in patients with seasonal allergic rhinitis and asthma. Int Arch Allergy Immunol (2003) 130:307-13. doi: $10.1159 / 000070218$

65. Simons FE. Is antihistamine (H1-receptor antagonist) therapy useful in clinical asthma? Clin Exp Allergy (1999) 29(Suppl 3):98-104 doi:10.1046/j.1365-2222.1999.0290s3098.x

66. Kanda N, Watanabe S. Histamine enhances the production of nerve growth factor in human keratinocytes. J Invest Dermatol (2003) 121:570-7. doi:10.1046/j.1523-1747.2003.12428.x

67. Giustizieri ML, Albanesi C, Fluhr J, Gisondi P, Norgauer J, Girolomoni G. H1 histamine receptor mediates inflammatory responses in human keratinocytes. J Allergy Clin Immunol (2004) 114:1176-82. doi:10.1016/j. jaci.2004.07.054

68. Mommert S, Gschwandtner M, Koether B, Gutzmer R, Werfel T. Human memory Th17 cells express a functional histamine $\mathrm{H} 4$ receptor. Am J Pathol (2012) 180:177-85. doi:10.1016/j.ajpath.2011.09.028

69. Smit MJ, Leurs R, Alewijnse AE, Blauw J, Van Nieuw Amerongen GP, Van De Vrede $\mathrm{Y}$, et al. Inverse agonism of histamine $\mathrm{H} 2$ antagonist accounts for upregulation of spontaneously active histamine $\mathrm{H} 2$ receptors. Proc Natl Acad Sci U S A (1996) 93:6802-7. doi:10.1073/pnas.93.13.6802

70. Fitzsimons CP, Lazar-Molnar E, Tomoskozi Z, Buzas E, Rivera ES, Falus A. Histamine deficiency induces tissue-specific down-regulation of histamine $\mathrm{H} 2$ receptor expression in histidine decarboxylase knockout mice. FEBS Lett (2001) 508:245-8. doi:10.1016/S0014-5793(01)03070-8

71. Meiler F, Zumkehr J, Klunker S, Ruckert B, Akdis CA, Akdis M. In vivo switch to Il-10-secreting T regulatory cells in high dose allergen exposure. J Exp Med (2008) 205:2887-98. doi:10.1084/jem.20080193

72. Lichtenstein LM, Gillespie E. The effects of the $\mathrm{H} 1$ and $\mathrm{H} 2$ antihistamines on "allergic" histamine release and its inhibition by histamine. J Pharmacol Exp Ther (1975) 192:441-50.

73. Teuscher C, Poynter ME, Offner H, Zamora A, Watanabe T, Fillmore PD, et al. Attenuation of Th1 effector cell responses and susceptibility to experimental allergic encephalomyelitis in histamine $\mathrm{H} 2$ receptor knockout mice is due to dysregulation of cytokine production by antigen-presenting cells. Am J Pathol (2004) 164:883-92. doi:10.1016/S0002-9440(10)63176-8

74. Dai H, Kaneko K, Kato H, Fujii S, Jing Y, Xu A, et al. Selective cognitive dysfunction in mice lacking histamine $\mathrm{H} 1$ and $\mathrm{H} 2$ receptors. Neurosci Res (2007) 57:306-13. doi:10.1016/j.neures.2006.10.020

75. Mobarakeh JI, Takahashi K, Sakurada S, Kuramasu A, Yanai K. Enhanced antinociceptive effects of morphine in histamine $\mathrm{H} 2$ receptor gene knockout mice. Neuropharmacology (2006) 51:612-22. doi:10.1016/j. neuropharm.2006.05.003 
76. Dimitriadou V, Rouleau A, Dam Trung Tuong M, Newlands GJ, Miller HR, Luffau G, et al. Functional relationship between mast cells and C-sensitive nerve fibres evidenced by histamine H3-receptor modulation in rat lung and spleen. Clin Sci (Lond) (1994) 87:151-63. doi:10.1042/cs0870151

77. Toyota H, Dugovic C, Koehl M, Laposky AD, Weber C, Ngo K, et al. Behavioral characterization of mice lacking histamine $\mathrm{H}(3)$ receptors. $\mathrm{Mol}$ Pharmacol (2002) 62:389-97. doi:10.1124/mol.62.2.389

78. Tokita S, Takahashi K, Kotani H. Recent advances in molecular pharmacology of the histamine systems: physiology and pharmacology of histamine $\mathrm{H} 3$ receptor: roles in feeding regulation and therapeutic potential for metabolic disorders. J Pharmacol Sci (2006) 101:12-8. doi:10.1254/jphs. FMJ06001X4

79. Yoshimoto R, Miyamoto Y, Shimamura K, Ishihara A, Takahashi K, Kotani $\mathrm{H}$, et al. Therapeutic potential of histamine $\mathrm{H} 3$ receptor agonist for the treatment of obesity and diabetes mellitus. Proc Natl Acad Sci U S A (2006) 103:13866-71. doi:10.1073/pnas.0506104103

80. Teuscher C, Subramanian M, Noubade R, Gao JF, Offner H, Zachary JF, et al. Central histamine $\mathrm{H} 3$ receptor signaling negatively regulates susceptibility to autoimmune inflammatory disease of the CNS. Proc Natl Acad Sci U S A (2007) 104:10146-51. doi:10.1073/pnas.0702291104

81. Lieberman P. The basics of histamine biology. Ann Allergy Asthma Immunol (2011) 106:S2-5. doi:10.1016/j.anai.2010.08.005

82. Suzuki S, Takeuchi K, Majima Y. Localization and function of histamine H3 receptor in the nasal mucosa. Clin Exp Allergy (2008) 38:1476-82. doi:10.1111/j.1365-2222.2008.03041.x

83. Wijtmans M, Leurs R, De Esch I. Histamine H3 receptor ligands break ground in a remarkable plethora of therapeutic areas. Expert Opin Investig Drugs (2007) 16:967-85. doi:10.1517/13543784.16.7.967

84. Leurs R, Bakker RA, Timmerman H, De Esch IJ. The histamine H3 receptor: from gene cloning to H3 receptor drugs. Nat Rev Drug Discov (2005) 4:107-20. doi:10.1038/nrd1631

85. de Esch IJ, Thurmond RL, Jongejan A, Leurs R. The histamine H4 receptor as a new therapeutic target for inflammation. Trends Pharmacol Sci (2005) 26:462-9. doi:10.1016/j.tips.2005.07.002

86. Nakamura T, Itadani H, Hidaka Y, Ohta M, Tanaka K. Molecular cloning and characterization of a new human histamine receptor, HH4R. Biochem Biophys Res Commun (2000) 279:615-20. doi:10.1006/bbrc.2000.4008

87. Liu C, Ma X, Jiang X, Wilson SJ, Hofstra CL, Blevitt J, et al. Cloning and pharmacological characterization of a fourth histamine receptor $(\mathrm{H}(4))$ expressed in bone marrow. Mol Pharmacol (2001) 59:420-6. doi:10.1124/ mol.59.3.420

88. Yamaura K, Shigemori A, Suwa E, Ueno K. Expression of the histamine H4 receptor in dermal and articular tissues. Life Sci (2013) 92:108-13. doi:10.1016/j.lfs.2012.10.030

89. Oda T, Morikawa N, Saito Y, Masuho Y, Matsumoto S. Molecular cloning and characterization of a novel type of histamine receptor preferentially expressed in leukocytes. J Biol Chem (2000) 275:36781-6. doi:10.1074/jbc. M006480200

90. Horr B, Borck H, Thurmond R, Grosch S, Diel F. STAT1 phosphorylation and cleavage is regulated by the histamine $(\mathrm{H} 4)$ receptor in human atopic and non-atopic lymphocytes. Int Immunopharmacol (2006) 6:1577-85. doi:10.1016/j.intimp.2006.06.005

91. Connelly WM, Shenton FC, Lethbridge N, Leurs R, Waldvogel HJ, Faull RL, et al. The histamine $\mathrm{H} 4$ receptor is functionally expressed on neurons in the mammalian CNS. Br JPharmacol (2009) 157:55-63. doi:10.1111/j.1476-5381.2009.00227.x

92. Medina VA, Rivera ES. Histamine receptors and cancer pharmacology. $\mathrm{Br}$ J Pharmacol (2010) 161:755-67. doi:10.1111/j.1476-5381.2010.00961.x

93. Breunig E, Michel K, Zeller F, Seidl S, Weyhern CW, Schemann M. Histamine excites neurones in the human submucous plexus through activation of H1, H2, H3 and H4 receptors. J Physiol (2007) 583:731-42. doi:10.1113/ jphysiol.2007.139352

94. Morgan RK, Mcallister B, Cross L, Green DS, Kornfeld H, Center DM, et al. Histamine 4 receptor activation induces recruitment of FoxP3+ T cells and inhibits allergic asthma in a murine model. J Immunol (2007) 178:8081-9. doi:10.4049/jimmunol.178.12.8081

95. Lim HD, Van Rijn RM, Ling P, Bakker RA, Thurmond RL, Leurs R. Evaluation of histamine H1-, H2-, and H3-receptor ligands at the human histamine H4 receptor: identification of 4-methylhistamine as the first potent and selective H4 receptor agonist. J Pharmacol Exp Ther (2005) 314:1310-21. doi:10.1124/ jpet.105.087965

96. Mirzahosseini A, Dalmadi B, Csutora P. Histamine receptor H4 regulates mast cell degranulation and IgE induced FcepsilonRI upregulation in murine bone marrow-derived mast cells. Cell Immunol (2013) 283:38-44 doi:10.1016/j.cellimm.2013.05.006

97. Ohsawa Y, Hirasawa N. The role of histamine $\mathrm{H} 1$ and $\mathrm{H} 4$ receptors in atopic dermatitis: from basic research to clinical study. Allergol Int (2014) 63:533-42. doi:10.2332/allergolint.13-RA-0675

98. Cowden JM, Yu F, Banie H, Farahani M, Ling P, Nguyen S, et al. The histamine $\mathrm{H} 4$ receptor mediates inflammation and Th17 responses in preclinical models of arthritis. Ann Rheum Dis (2014) 73:600-8. doi:10.1136/ annrheumdis-2013-203832

99. Morse KL, Behan J, Laz TM, West RE Jr, Greenfeder SA, Anthes JC, et al. Cloning and characterization of a novel human histamine receptor. J Pharmacol Exp Ther (2001) 296:1058-66.

100. Hinz M, Arslan SC, Scheidereit C. It takes two to tango: IkappaBs, the multifunctional partners of NF-kappaB. Immunol Rev (2012) 246:59-76. doi:10.1111/j.1600-065X.2012.01102.X

101. Ahmad SF, Ansari MA, Zoheir KM, Bakheet SA, Korashy HM, Nadeem A, et al. Regulation of TNF-alpha and NF-kappaB activation through the Jak/ Stat signaling pathway downstream of histamine 4 receptor in a rat model of LPS-induced joint inflammation. Immunobiology (2015) 220:889-98. doi:10.1016/j.imbio.2015.01.008

102. Thurmond RL, Chen B, Dunford PJ, Greenspan AJ, Karlsson L, La D, et al. Clinical and preclinical characterization of the histamine $\mathrm{H}(4)$ receptor antagonist JNJ-39758979. J Pharmacol Exp Ther (2014) 349:176-84. doi:10.1124/jpet.113.211714

103. Savall BM, Chavez F, Tays K, Dunford PJ, Cowden JM, Hack MD, et al. Discovery and Sar of 6-alkyl-2,4-diaminopyrimidines as histamine $\mathrm{H}$ (4) receptor antagonists. J Med Chem (2014) 57:2429-39. doi:10.1021/ jm $401727 \mathrm{~m}$

104. Amin K. The role of mast cells in allergic inflammation. Respir Med (2012) 106:9-14. doi:10.1016/j.rmed.2011.09.007

105. Cruse G, Bradding P. Mast cells in airway diseases and interstitial lung disease. Eur J Pharmacol (2016) 778:125-38. doi:10.1016/j.ejphar.2015.04.046

106. Church MK, Church DS. Pharmacology of antihistamines. Indian J Dermatol (2013) 58:219-24. doi:10.4103/0019-5154.110832

107. Shim YK, Kim N. The effect of $\mathrm{H} 2$ receptor antagonist in acid inhibition and its clinical efficacy. Korean J Gastroenterol (2017) 70:4-12. doi:10.4166/ kjg.2017.70.1.4

108. Thurmond RL, Venable J, Savall B, La D, Snook S, Dunford PJ, et al. Clinical development of histamine H4 receptor antagonists. Handb Exp Pharmacol (2017) 241:301-20. doi:10.1007/164_2016_130

109. Schwartz JC. The histamine H3 receptor: from discovery to clinical trials with pitolisant. Br JPharmacol (2011) 163:713-21. doi:10.1111/j.1476-5381.2011.01286.x

110. Mishra GP, Tamboli V, Jwala J, Mitra AK. Recent patents and emerging therapeutics in the treatment of allergic conjunctivitis. Recent Pat Inflamm Allergy Drug Discov (2011) 5:26-36. doi:10.2174/187221311794474883

111. Nguyen T, Shapiro DA, George SR, Setola V, Lee DK, Cheng R, et al. Discovery of a novel member of the histamine receptor family. Mol Pharmacol (2001) 59:427-33. doi:10.1124/mol.59.3.427

112. Zhu Y, Michalovich D, Wu H, Tan KB, Dytko GM, Mannan IJ, et al. Cloning, expression, and pharmacological characterization of a novel human histamine receptor. Mol Pharmacol (2001) 59:434-41. doi:10.1124/mol.59.3.434

113. Dunford PJ, Williams KN, Desai PJ, Karlsson L, Mcqueen D, Thurmond RL. Histamine $\mathrm{H} 4$ receptor antagonists are superior to traditional antihistamines in the attenuation of experimental pruritus. J Allergy Clin Immunol (2007) 119:176-83. doi:10.1016/j.jaci.2006.12.606

114. Nakano Y, Takahashi Y, Ono R, Kurata Y, Kagawa Y, Kamei C. Role of histamine $\mathrm{H}(4)$ receptor in allergic conjunctivitis in mice. Eur J Pharmacol (2009) 608:71-5. doi:10.1016/j.ejphar.2009.02.035

115. Rossbach K, Wendorff S, Sander K, Stark H, Gutzmer R, Werfel T, et al. Histamine $\mathrm{H} 4$ receptor antagonism reduces hapten-induced scratching behaviour but not inflammation. Exp Dermatol (2009) 18:57-63. doi:10.1111/j.1600-0625.2008.00762.x 
116. Cowden JM, Zhang M, Dunford PJ, Thurmond RL. The histamine H4 receptor mediates inflammation and pruritus in Th2-dependent dermal inflammation. J Invest Dermatol (2010) 130:1023-33. doi:10.1038/jid.2009.358

Conflict of Interest Statement: The authors declare that the research was conducted in the absence of any commercial or financial relationships that could be construed as a potential conflict of interest.
Copyright $\odot 2018$ Thangam, Jemima, Singh, Baig, Khan, Mathias, Church and Saluja. This is an open-access article distributed under the terms of the Creative Commons Attribution License (CC BY). The use, distribution or reproduction in other forums is permitted, provided the original author(s) and the copyright owner(s) are credited and that the original publication in this journal is cited, in accordance with accepted academic practice. No use, distribution or reproduction is permitted which does not comply with these terms. 